\title{
Temple Art and Icon Painting at The Universities - the Spiritual Formation of Students in Russia
}

\author{
G. A. Rebinsky*, E. S. Gamov*, A. V. Martynova*, S. B. Tonkovid* \\ * Lipetsk State Technical University, Russia \\ ${ }^{I}$ Affiliation of the first author \\ ${ }^{2}$ Affiliation of the second author \\ ${ }^{3}$ Affiliation of the third author \\ *Corresponding author E-mail:
}

\begin{abstract}
This article shows the results of the research of the term "icon". The importance of icons in the Orthodox Church is shown. The main aspects of the methodology of making icons, traditions and modern problems in church art are described. The main aspects of the methodology of making icons, traditions and modern problems in church art are described. Information on achievements in the field of icon painting at the Lipetsk State Technical University is adduced. (FSEI HE «LSTU»)
\end{abstract}

Keywords:

\section{Introduction}

Temple art and icon painting is carried out in FSEI HE "LSTU" theoretically and practically in the educational disciplines: "Basics of Orthodox Culture", "Church Slavonic Language" and "Theology" in two directions of educations "Technology of artistic processing of materials" and "Design", where the key notion is the "icon". The research of the term "icon", the study of the conditions for creating Orthodox icons for traditional Russian culture, as well as practical work on their creation, will allow us to better understand the concept of Russian art and develop a scientific and practical foundation for Russian design. The study of iconography also contributes to the search for new means of expressiveness in design, improving the quality of design objects, the development of Russian style.

\section{Method of Research}

The research was carried out by methods of studying, summarizing and analyzing of various information sources, photographing samples of iconography, measuring the aesthetic properties of art works and comparing the data obtained, also by interviewing consumers and experts in the field of church art.

Based on the data obtained using the modeling method, a number of works in the field of iconography were performed. Among them - the creation of an interior in the Evdokievsky church in Lipetsk (Russia). The most significant practical works, reflecting the results of this study, were the icons "Our Lady of Vladimir" and "The Holy Apostle Paul", made at FSEI HE "LSTU".

\section{Results and Analysis}

As a result of the research it was established that the word (term) "icon", according to [1-3] Greek origin, including [2]: eikon image, portrait, in Orthodoxy and Catholicism the image of Jesus Christ, the Mother of God and saints. It is also known that in the early period of the emergence of Christian art in Byzantium, the term eikon had in mind any image of the Savior, the Mother of God, the saint, the angel and the events of Sacred History in general, regardless of the technique of execution. In consequence, over time, the term began to be applied mainly to the icon of the icon, which is made with paints, carvings, mosaics. Its peculiarity is that it is written on the board and is itself an object, in contrast to the wall painting, which represents one whole with the wall. However, their meaning and meaning, according to [3], are one and the same, and the difference is only in the use and purpose of one or the other. And further, when they talk about icons, they mean the church image in general, whether painted in colors on a board, made on the wall by fresco, mosaic or sculpture. That is, the Russian word "image", like the French "image", has a very broad meaning and applies to all kinds of images [4, 3].

In the dictionary - a reference book on contemporary art [5], it confirms what was said about the term "icon", but unlike the data $[1,3]$, it is a pictorial image that builds the feeling of a person praying to the depicted primal image.

In the modern dictionary of church words and expressions [1], "icon" is the Church's accepted and sainted image of Christ, the Mother of God, saints and various events from the Sacred and Church history. And the icons themselves are written according to strictly defined rules with paints (tempera or oil) on a board covered with a pallet (cloth) and gesso.

A number of theological works draw attention to the very great importance assigned to the icon in the Orthodox Church. Thus, in work [3] it is shown: "... an icon is something much more than just 
an image: it is not only the decoration of a temple or illustration of Holy Scripture, it is its complete correspondence, an object organically entering the liturgical life." This explains the significance that the Church betrays the Orthodox icon, that is, not to any image at all, but to that specific image that it itself developed during its history, in the struggle against paganism and heresies, to the image for which it paid blood during the Iconoclast period a host of martyrs and confessors.

Characteristic is that, according to L. A. Uspensky, in the icon the Church sees not one aspect of Orthodox teaching, but the expression of Orthodoxy in its whole, Orthodoxy as such. Hence it follows that the icon as an image of the sacred is one of the manifestations of the church Tradition, along with the Tradition recorded and the oral Tradition. And the veneration of the icons of the Savior, the Mother of God, angels and saints is the dogma of the Christian faith, worked out by the Seventh Ecumenical Council, a dogma that follows from the basic confession of the Church, namely, the incarnation of the God Son. Hence, the icon of the Son of God is a testament to the true, and not illusory, His incarnation. Therefore, not infrequently, icons are rightly called "theology in colors". The meaning of the image most fully reveals the canons and stichera of the holidays, dedicated to various icons, for example, the Savior Not Made by Hands and especially the service of the triumph of Orthodoxy.

Thus, the study of the content and meaning of the icon is a theological subject, like the study of Holy Scripture. It should be noted that, according to [3], the Church constantly opposed the secularization of church art. Thus, by the voice of her Councils, saints and believing laymen, she defended him against the penetration of elements alien to him, which are characteristic of the fine arts of the world. It is also indicated in [3] that we must not forget that when the idea in the religious sphere was not always at the height of theology, so art creativity was not always at the height of the true iconography.

In connection with the foregoing, [3] stresses that "... every image can not be considered an infallible authority, even if it is very ancient and very beautiful, and even less so if it was created in an era of decline, in our kind." And then a very important conclusion: "So the image can correspond to the teaching of the Church, or it may not correspond, can be misleading, instead of instructing. In other words, the teaching of the Church can be distorted in the same way as a word. Therefore, the Church has always fought not for the artistic quality of its art, but for its authenticity, not for its beauty, but for its truth "[3].

When you run the list, you need to solve three problems. The first is to find the prototype in the form of icon-painting originals, to adopt the basis of icons and colorful materials. If on the basis of the icon and its colorful materials, according to $[6,7]$, there are absolutely certain recommendations that it is a board or a wooden shield made of different types of wood, when the advantage is given to a lime or a piled canvas. As a colorful layer, the priest Michael Maleev [7] unequivocally points to egg emulsion and mineral pigments. In turn, the nun Juliana [6] believes that the paint layer in the icon can be made using an artificial temperament that is, casein - oil or polyvinyl acetate. However, the abbot Alexander (Fedorov) [4], referring to the definition of the Seventh Ecumenical Council, suggests the possibility of using various materials to create sacred images. It is known that various materials give birth to a variety of technologies, but there are certain preferences that are given in the iconography to tempera technique. And this is not accidental, since this circumstance determines not only a specific, highly ecological and symbolizing life, a connecting ingredient - a chicken egg, but also the order of actions of the icon painter, almost sacred actions. And also the images of the divine presence - for gold (in the background, halos and assists), behind the various techniques that express the presence of Light, are of special importance.

However, let us return to the first problem, which lies in the search for an icon-painting original of the image. This problem is complex and diverse, which occurs, as was shown above, from the theology of the image, which is one of the most important dogmatic aspects of the teaching of the Orthodox Church. According to [4], it is not only about the icon in the exact sense of the word, but through the icon as a special "pearl" in the series of figurativesymbolic system of theology of the image, it reveals itself in different aspects.

Given the foregoing, as well as the need to choose an image, is it generally relevant to be critical of the icon? In work [8] it is said: "No," some Orthodox believers will object, "the icon is sacred, and it is unacceptable to criticize it for us as a sinner." And further: "Although everyone knows that God's grace does not depend on the mastery of the icon painter, and even with the mistakes of the master, the icon can be miraculous, clergymen, bishops who performed censorship in the 19th and early 20th centuries, found it necessary to publish critical articles in order to improve the icon painting in Russia".

Among the 15 critical articles published in the collection [8], attention is drawn to the article by L.I. Denisov "What are the requirements an Orthodox icon should satisfy?", Which, as an abstract, was read on December 12, 1900 at a meeting of the ChurchArchaeological Department at the society of lovers of spiritual enlightenment and published in 1901.

It should be noted that L.I. Denisov - a well-known spiritual writer, possessed a huge erudition, who spoke many foreign languages. A graduate of Moscow University, he accepted a monastic order with the name Arseny. It is believed that he served in the bosom of the Russian Orthodox Church in the office of Bishop Kashirsky, vicar of the Moscow diocese, who ceased to rule in December 1931. However, neither the year nor the place of his death is known [8].

In the article L.I. Denisov, who was published in the collection [8] "What requirements should an Orthodox icon satisfy?", It is said that in the symbolic image on the icon of the Savior - a crossed halo with letters, the great meaning of this word is often distorted Jehovah, when put in the place of the Greek "omega" Slavic "ot". Now in the iconography for the symbolic image on the icons of the Savior is used the Slavic alphabet.

The Savior of Sinai, that is, the icon of the sixth century from the monastery of St. Catherine, possesses the greatest degree of authenticity of the image of the Lord according to the New Testament of our Lord Jesus Christ (2009).

On the basis of the above data, a number of practical works in the field of iconography were carried out at FSEI HE "LSTU". Among the most significant, taking into account the guidance on the writing of the icons of the saints of God [9], one should include the icons "Our Lady of Vladimir" and "The Holy Apostle Paul". The icon "Our Lady of Vladimir" was maid by the third year student Olina T. E. on canvas with oil paints. For this, she was sent to the Tretyakov Gallery, or rather to the temple adjacent to her, where her original is kept. On her return from a trip Olina T. E. performed a list of icons for the Evdokievsky church (Lipetsk), where he is currently. Thus, spiritual preparation, typical for icon painters when writing the holy image, was carried out, which made it possible to fulfill the list, which is one of the dominants of the temple interior and has a favorable effect on visitors.

As you know, there are various techniques that express the presence of Light in the icon. One of the examples among the more local technical ways of reflecting theological thought in a sacred image [4] is the diversion of the colorful layer on the Vladimir Icon of the Mother of God. This phenomenon was reproduced in the list of icons "The Holy Apostle Paul". This icon was made by us on the former student's drawing board, according to the technology described in work [7]. Applied technology also allowed us to reproduce in the icon "Saint Apostle Paul" another phenomenon - luminosity, characteristic of Byzantine and Old Russian art. A survey of viewers showed that the icon, under the influence of the light falling on it, "flickers."

Temple art and icon painting were demonstrated by us at various exhibitions, competitions, fairs, including abroad, where they were highly appreciated - were awarded a gold medal. These achieve- 
ments of FSEI HE "LSTU", in which both students and teachers of professorial chair "Design and artistic processing of materials" took part, reflect one of the directions of Orthodox culture in social and conciliar service [10]

\section{Conclusion}

1. It is established that the term "icon" comes from eikon - an image, a portrait, in Orthodoxy and Catholicism the image of Jesus Christ, the Mother of God and the saints. The term means the church image in general, executed in any technique, has a very broad meaning and applies to all kinds of images.

2. Of all the church images, a prayer icon stands out, written on the board and is itself an object. It is carried out according to strictly defined rules by paints on a board covered with a pallet (cloth) and gesso.

3. A distinctive feature of the Orthodox icon from any image in general is that it is a specific image that the Church has developed throughout its history, full correspondence to the Holy Scripture, an object organically entering the liturgical life, the expression of Orthodoxy in its entirety, one of the manifestations Church Tradition, a pictorial image that elevates the feeling of the person praying to the depicted primal image.

4. The special relation to the icon (veneration) is connected with the dogma of the Christian faith, which derives from the basic confession of the Church, namely: the incarnation of the Son of God.

5. The study of the content and meaning of the icon is theological. However, throughout Christian history, thought in the religious realm has not always been at the height of theology. Therefore, in the history of iconography there were both periods of prosperity and decline (secularization), when the image distorts the Church's teaching, it deceives, instead of instructing.

6. Throughout its history, the Church has always fought not for the artistic quality of its art, but for its authenticity, not for its beauty, but for its truth.

7. In the technique of icon painting, preference is given to egg tempera because the chicken egg is a highly ecological and lifesymbolizing binder ingredient. The order of the icon-painter's actions is similar to the sacred action: from the proris and gilding through the "slides", architecture and vestments - to personal writing, assist (golden cutting) and writing. The golden background is the image of the divine presence.

8. A characteristic feature on the icon of the Savior is a symbolic image of a crossed halo with letters denoting the word "Jehovah". At the same time, icon painters often distort the great meaning of this word when they write the Slavic "ot" in the place of the Greek "omega".

9. The Savior of Sinai - the icon of the VI century from the monastery of St. Catherine possesses the greatest authenticity of the image of Jesus Christ.

10. On the basis of the above-mentioned results of the research, the icons "Our Lady of Vladimir" and "The Holy Apostle Paul" were made at FSEI HE "LSTU".. Analysis of these products and the results of their exposure showed the need for spiritual preparation for the iconography process, as well as the reproducibility of medieval technologies and the phenomenon of luminosity, which in our opinion should become a new aesthetic property of design and artistic materials processing objects.

\section{References}

[1] Priest, A.L, (2000), A book about the church, Moscow: Pilgrim, p. 380.

[2] Prokhorov, Ch. Ed. A.M, (1983), Soviet Encyclopaedic Dictionary, 2 nd ed, Moscow: Soviet Encyclopedia, p. 1600.

[3] Uspensky, L.A, (2007), Theology of the icon of the Orthodox Church, Moscow: Dar, p. 480.
[4] Hegumen A, (2007), Church art as a spatial-visual complex. - St. Petersburg: Satis, p. 223.

[5] Melik-Pashayev, A.A, (1999), Modern Dictionary of Art Reference, ed, Moscow: Publishing house AST, p. 816

[6] Sokolova, M.N, (2008), The nun of Juliana, Work of the icon painter, Sergiev Posad: Holy Trinity Sergius Lavra, p. 351.

[7] Priest M.M, (2002), The technique of Russian icon painting, - Moscow: Parish of the Holy Virgin Protection Church in Bratsev, p. 104

[8] About church painting, Parts one and two (Collection of articles), St. Petersburg: "Society of St Basil the Great", 1998, p. 384.

[9] Fartusov, V.D, (2002), Guide to the writing of icons of God's saints in the order of the days of the year, A handbook for icon painters, Moscow: "The Russian Chronograph", p. 451.

[10] Kalinicheva, M.M., Gamov, ES., Tonkovid, S.B, (2017), Orthodox culture in social and conciliar service, Theory and practice of machine-building design and tourism, Collection of scientific works of the International Scientific and Practical Conference dedicated to the 60th anniversary of the Lipetsk State Technical University and the 20th anniversary of professorial chair "Design and artistic processing of materials" of the Institute of Mechanical Engineering, p. $61-74$ 